\title{
KOMPUTERISASI INFORMASI BILLING PADA PT. MNC SKY VISION MENGGUNAKAN BAHASA PEMROGRAMAN PHP
}

\author{
Nur Rubiati ${ }^{1,}$ Kalvin Pasaribu', \\ ${ }^{1,2}$ Sekolah Tinggi Manajemen Informatika Dan Komputer ( STMIK ), Dumai, Riau \\ Jln. Utama Karya Bukit Batrem Dumai-Riau Kode Pos 28811 \\ Email :nurrubiati@mail.stmikdumai.ac.id ${ }^{1}$,Kpasaribu29@gmail.com²
}

\begin{abstract}
ABSTRAK
PT.MNC SKY VISION membutuhkan teknologi komputerisasi untuk membantu proses kebutuhan dalam perkembangan usaha dan pengolahan data. Sistem pengolahan data secara manual dinilai lambat dan membutuhkan waktu yang lama dalam memproses pencarian data yang lama. Pengolahan data di MNC SKY VISION Dumai masih dilakukan secara manual, yaitu mencatat jumlah seluruh pelanggan, dan jumlah barang keluar di buku besar atau (form stock opname). Ruang penyimpanan data kurang memadai, untuk data barang masuk dan data barang keluar yang berjangka waktu lama. Hal itu mengakibatkan penumpukkan data yang lama tidak terstruktur dengan rapi dan bertentangan dengan standar komputerisasi, serta belum adanya media penghubung antara pihak kepala gudang dan manager dalam penyampaian informasi yang menjadi masalah tersendiri dan perlu ditangani lebih lanjut. Pada aplikasi yang dirancang akan mampu memberikan manfaat dan efisiensi di PT MNC SKY VISION.
\end{abstract}

Kata Kunci : Komputerisasi, Informasi, Billing, PHP

\section{PENDAHULUAN}

PT. MNC SKY VISION Tbk sebelumnya bernama PT Matahari Lintas Cakrawala, adalah perusahaan yang terlibat dalam operasi televisi berlangganan pertama di Indonesia. Perusahaan yang didirikan pada tanggal 8 agustus 1988 ini memulai memasarkan produk jasanya pada awal tahun 1994 dan bertanggung- jawab atas pemasaran program pengelolaan serta pelayanan kepada pelanggan.

Billing berasal dari bahasa Inggris yaitu bill (noun), yang artinya bukti transaksi pembayaran. Maka billing dapat juga diartikan mengirimkan bukti transaksi, atau mengumumkan bukti transaksi.

Billing Software sangat berguna pada usaha-usaha mata pencaharian di atas terutama yang akan dibahas kali ini yaitu manfaat Billing Software untuk PT.MNC SKY VISION. Dengan Billing Software admin dapat berjalan lancar karena kita dapat menghitung dan mencatat tarif, waktu dan jenis penyewaan secara tepat. Begitu banyak keuntungan apabila kita menggunakan Billing Software dalam usaha. Diantaranya tadi seperti yang disebutkan sebelumnya, tidak akan ada yang saling dirugikan antara pihak pelanggan dengan pemilik, selain itu untuk pihak pemilik tidak perlu khawatir akan kecurangan pegawai (admin) dalam menjaga usaha pemilik tersebut, karena semua kegiatan jual beli jasa akan tercatat pada Billing Software.

Setelah mengerti tentang bagaiman sistem billing bekerja dan juga perangkat yang dibutuhkan secara umum, perlu kita tahu sejauh mana kemampuan sistem Billing itu. Pada dasarnya setiap software sistem Billing memiliki kemampuan yang sama yaitu sebagai pemonitor transaksi yang terjadi pada setiap badan atau usaha yang menggunakannya. Tetapi selanjutnya masing-masing pengguna mengembangkannya ke arah yang berbeda-beda, sehingga akhirnya memiliki kemampuan lebih yang berbeda tiap sistem.

Karena kebutuhan informasi terbaru tagihan pelanggan Indovision, khususnya informasi tagihan bulanan sangat di perlukan terutama pada pelangan yang ingin mengetahui jumlah tagiahan setiap bulannya.serta ketersediaan Internet yang sangat mudah di akses di manapun dan kapanpun kita berada, maka mengangkatnya menjadi bahan proposal skripsi yang hasilnya tersedianya suatu media online yang khusus untuk pelanggan Indovision yang ingin mengetahui jumlah tagihan setiap bulannya. PT.MNC SKY VISION belum memilki sebuah sistem komputerisasi yang berbasis web, yang memudahkan admin 
I N F O R M A T I A

Jurnal Informatika, Manajemen dan Komputer, Vol. 8 No. 2 , Desember 2016

eISSN : 2580-3042

pISSN : 1979-0694

untuk mengakses data pelanggan. Dalam hasil penggolahan data kurangnya media penyimpanan untuk data atau aplikasi pelanggan yang berjangka waktu lama. Mengakibatkan penyimpanan data tidak terstruktur, dan data-data yang lama bisa saja rusak atau hilang.

\section{a. Pengertian Sistem}

Secara sederhana sistem dapat diartikan sebagai suatu kumpulan atau himpunan dari unsur atau variabel yang saling terorganisasi, saling berinteraksi dan saling bergantung satu sama yang lainnya

Sistem adalah suatu jaringan kerja dari prosedur-prosedur yang saling berhubungan, berkumpul bersama-sama untuk melakukan suatu kegiatan atau untuk menyelesaikan suatu sasaran tertentu (Jogiyanto, 2009:h.1).

Definisi sistem dari berbagai sumber dapat dilihat sebagai berikut:

1. Sistem adalah Sebuah tatanan (keterpaduan) yang terdiri atas sejumlah komponen fungsi (dengan satuan fungsi atau tugas khusus) yang saling berhubungan dan secara bersama-sama bertujuan untuk memenuhi suatu proses atau kegiatan tertentu (Fathansyah, 2010:h.9).

2. Sistem adalah suatu kumpulan atau himpunan dari unsur, komponen atau variabel-variabel yang terorganisasi, saling berinteraksi, saling tergantung satu sama lain dan terpadu (Tata Sutabri, 2012:h.3).

3. Sistem adalah kumpulan dari elemenelemen yang berinteraksi untuk mencapai suatu tujuan tertentu (Jogiyanto Hartono, 2009:h.2).

Berdasarkan Uraian diatas sistem adalah merupakan sekumpulan elemen-elemen yang saling berinteraksi untuk mencapai suatu tujuan tertentu.

\section{b. Pengertian Komputerisasi.}

Komputerisasi adalah perubahan pengolahan data manual kepada pengolhan data dengan menggunakan alat bantu computer. Dengan adanya komputer sebagai alat bantu manusia, telah memberikan kemudahankemudahan mulai dari pemecahan perhitungan yang rumit, pembukuan, pembuatan grafik, komunikasi dan sebagainya. John J. Longkutoy (2009)

\section{c. Pengertian Informasi.}

Informasi adalah, data yang diolah menjadi bentuk yang lebih berguna dan lebih berarti bagi yang menerimanya. Sumber dari

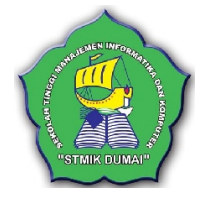

informasi adalah data. Data merupakan bentuk jamak dari bentuk tunggal datum atau data item. Data adalah kenytaan yang menggambarkan suatu kejadian-kejadian dan kesatuan nyata. (Jogiyanto, 2009:11).

\section{d. Pengertian Billing}

Billing berasal dari bahasa Inggris yaitu bill (noun), yang artinya bukti transaksi pembayaran. Maka billing dapat juga diartikan mengirimkan bukti transaksi, atau mengumumkan bukti transaksi.

\section{METODOLOGI PENELITIAN}

Dalam penulisan ini Metodologi penelitian yang akan digunakan adalah sebagai berikut :

a. Tempat dan Waktu Penelitian

Penelitian dilakukan pada PT.MNC SKY VISION Dumai yang beralamat dijalan Patimura Dumai, dan waktu penelitian dimulai dari pagi hari jam 08.00 Wib sampai dengan jam $17.00 \mathrm{Wib}$.

b. Jenis Penelitian

1. Penelitian lapangan (Field Research) Yaitu memudahkan observasi langsung kelapangan untuk men-dapatkan datadata yang diperlukan serta untuk mengetahui dengan rinci permasalahan yang menghambat, untuk itu dilakukan wawancara langsung dengan pihakpihak yang terkait dengan permasalah yang dibahas dalam penelitian ini.

2. Penelitian kepustakaan (Library Research)

Merupakan satu cara untuk mendapatkan satu data, mencari solusi atas penyelesaian masalah dengan bantuan buku-buku yang ada serta media lainnya.

3. Penelitian Labor (Laboratory Research) Penelitian lain yang juga dilakukan adalah penelitian labor, dalam hal ini sarana penunjang yang digunakan dalam penyelesaian program dan pengetikannya.

c. Teknik Analisa Data.

Teknik analisa data berisi tentang analisa yang berisi tentang teknik analisis data yang digunakan sepeti:

a. Analisis Kualtatif.

dengan menganalisis secara kulitatifbaik dengan mengumpulkan data, wawan cara, maupun obserpasi

b. Analisis kuantitatif.

Dengan menggunakan statistik interensial untuk menganalisis data-data yang telah 
I N F ORM I T I K

Jurnal Informatika, Manajemen dan Komputer, Vol. 8 No. 2 , Desember 2016

eISSN : 2580-3042

pISSN : 1979-0694

dikuantifikasi, datayang diperllukan seperti laporan pembayaran TV berlangganan.

\section{HASIL DAN PEMBAHASAN \\ a. Implementasi Sistem \\ Form Login}

Untuk menjalankan program layanan TV

MNC SKY VISION Dumai, terlebih dahulu pengguna harus login untuk mengakses halaman sistem. Adapun cara untuk mengakses form login adalah sebagai berikut:

1. Buka sistem MNC Sky Vision Dumai.

2. Input kan username, password serta level akses.

3. Klik tombol login untuk mengakses halaman. Jika username, password dan level diterima sistem maka pengguna akan dialihkan kehalaman sesuai level akses.

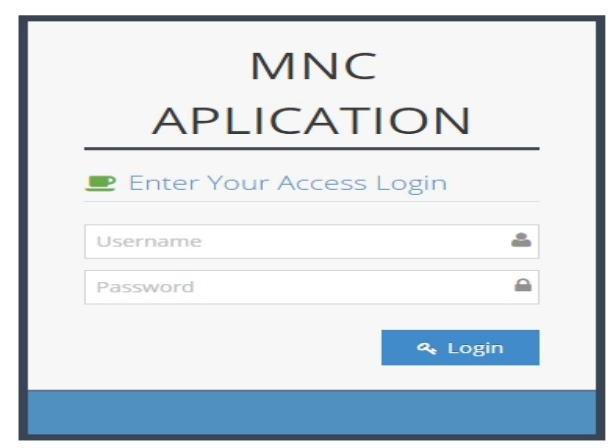

Gambar 1. Form Login

Pada halaman ini merupakan tampilan utama halaman. Pada halaman ini semua data dapat diakses. Halaman utama memiliki banyak menu akses dari akses data customer, data user data layanan tv, data pemasangan, data pembayaran , data, monitoring data layanan customer, dan laporan.

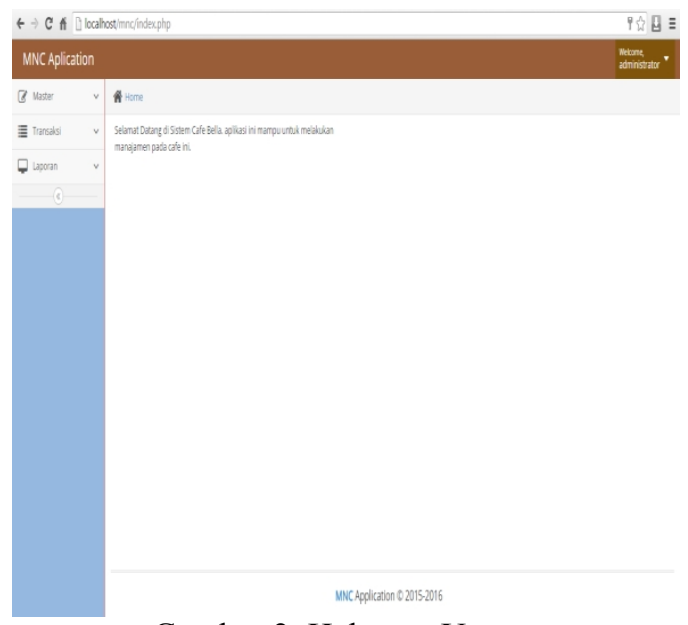

Gambar 2. Halaman Utama
Pada halaman ini pengguna dapat mengakses dan memanipulasi data layanan tv yang ada. Pengguna dapat menginput, mengubah dan juga menghapus data layanan tv yang ada disistem. Ada pun cara menginput data layanan tv ialah :

1. Pada halaman utama klik menu master

2. Setelah itu klik sub menu layanan tv, maka tampilan data layanan tv akan muncul.

3. Untuk menginput data layanan tv baru, isi lah form yang telah disediakan seperti kode layanan, brand, chanel dan lainya.

4. Setelah selesai klik tombol simpan jika data sudah terisi semua. Maka data akan tersimpan ke database.

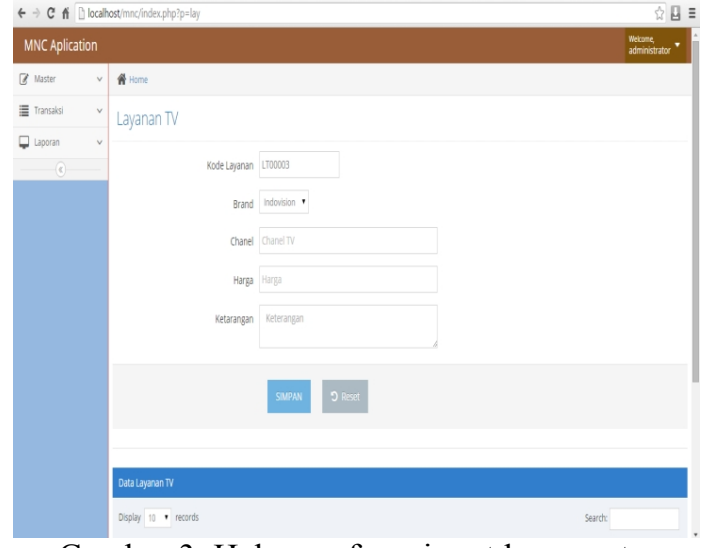

Gambar 3. Halaman form input layanan tv

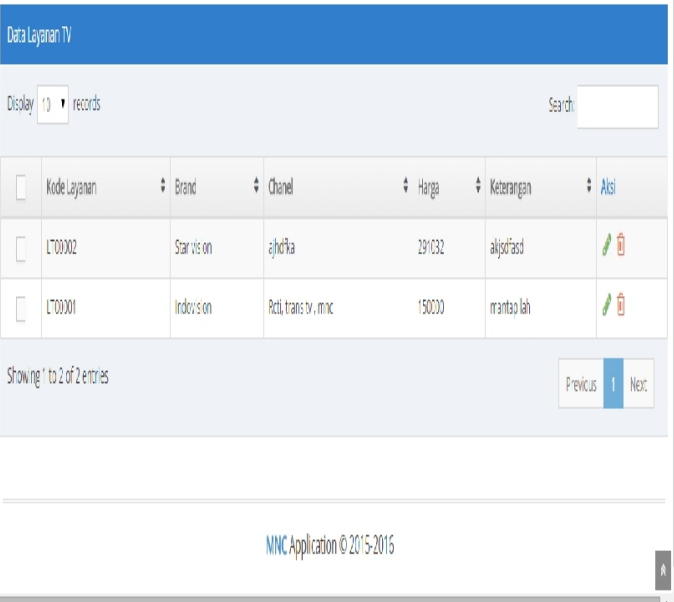

Gambar 4. Halaman Data layanan tv

Pada halaman ini pengguna dapat mengakses dan memanipulasi data customer yang ada. Pengguna dapat menginput, mengubah dan juga menghapus data customer yang ada disistem. Ada pun cara menginput data customer ialah :

1. Pada halaman utama klik menu master

2. Setelah itu klik sub menu customer, maka tampilan data customer akan muncul. 
I N F O R M A T I K

Jurnal Informatika, Manajemen dan Komputer, Vol. 8 No. 2 , Desember 2016

eISSN : 2580-3042

pISSN : 1979-0694

3. Untuk menginput data customer baru, isi lah form yang telah disediakan seperti kode customer, nama, no ktp, alamat dan lainya.

4. Setelah selesai klik tombol simpan jika data sudah terisi semua. Maka data akan tersimpan ke tabel customer pada database.

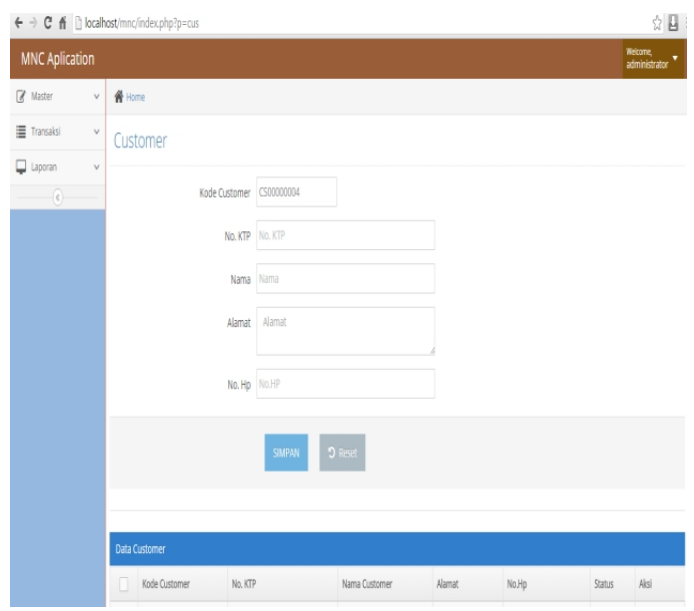

Gambar 5. Halaman Form input data customer

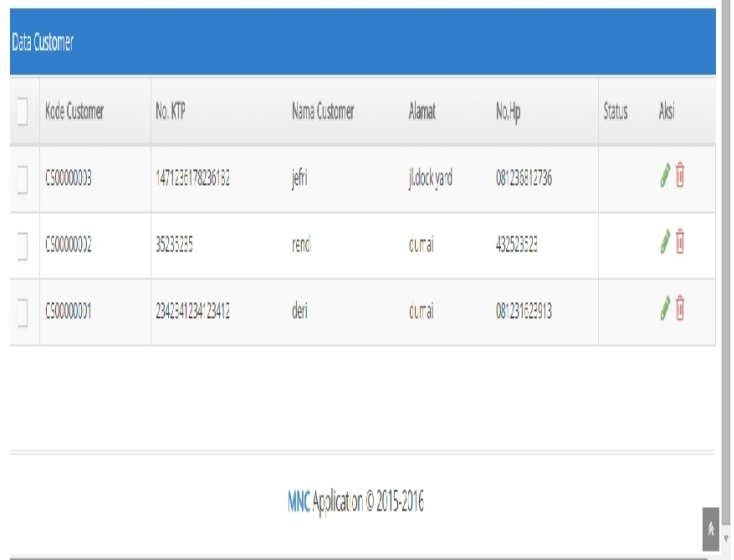

Gambar 6. Halaman Data Customer

Pada halaman ini pengguna dapat mengakses dan memanipulasi data user yang akan mengakses sistem. Pengguna dapat menginput, mengubah dan juga menghapus data user yang ada disistem.

Ada pun cara menginput data user ialah :

1. Pada halaman utama klik menu master

2. Setelah itu klik sub menu user, maka tampilan data user akan muncul.

3. Untuk menginput data user baru isi lah form yang telah disediakan seperti username dan pasword.

4. Setelah selesai klik tombol simpan jika data sudah terisi semua. Maka data akan tersimpan ke tabel users pada database.

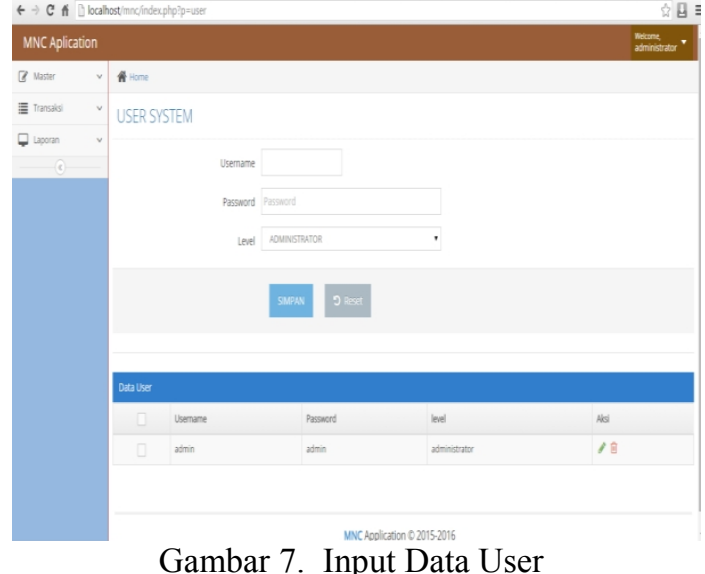

Gambar 7. Input Data User

Pada halaman ini pengguna dapat mengakses dan memanipulasi data pemasangan layanan tv. Pengguna dapat menginput, dan juga menghapus data pemasangan layanan tv yang ada disistem. Ada pun cara menginput pemasangan layanan tv ialah :

1. Pada halaman utama klik menu transaksi

2. Setelah itu klik sub menu pemasanagan, maka tampilan data pemasangan layanan tv akan muncul.

3. Untuk menginput data pemasangan layanan tv baru, isi lah form yang telah disediakan seperti kode customer, brand chanel dan tanggal jatuh tempo. Untuk kode pemasangan akan otomatis muncul beserta tanggal.

4. Setelah selesai klik tombol simpan jika data sudah terisi semua. Maka data akan tersimpan ke tabel pemasangan pada database.

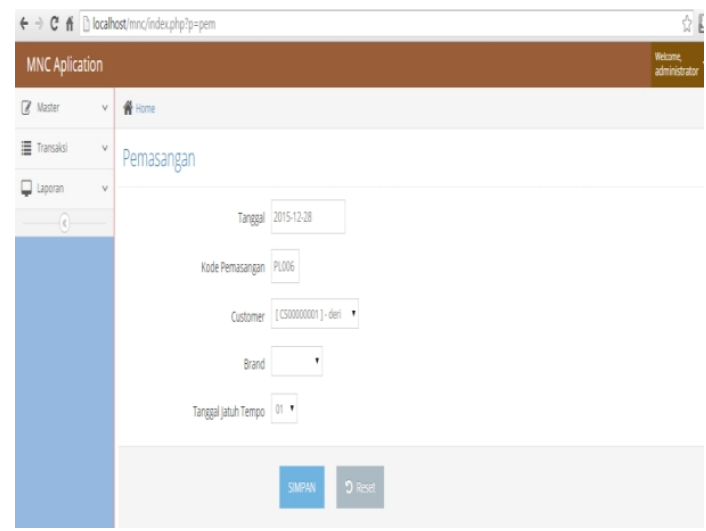

Gambar 8. Halaman Input Data Pemasangan Layanan TV

Pada halaman ini pengguna dapat mengakses dan memanipulasi data pembayaran layanan tv. Pengguna dapat menginput, dan juga menghapus data pembayaran layanan tv yang ada disistem. 
I N F O R M A T I K

Jurnal Informatika, Manajemen dan Komputer, Vol. 8 No. 2 , Desember 2016

eISSN : 2580-3042

pISSN : 1979-0694

Ada pun cara menginput data pembayaran layanan tv ialah :

1. Pada halaman utama klik menu transaksi

2. Setelah itu klik sub menu pembayaran, maka tampilan data pembayaran layanan tv akan muncul.

3. Untuk menginput data pembayaran layanan tv isi lah form yang telah disediakan. Untuk kode customer pilih customer dari combobox dan klik tombol tampil, maka data customer pada pemasangan layanan akan muncul berserta tagihan bayar baik pasang baru maupun bayar layanan tv.

4. Setelah selesai klik tombol simpan jika data sudah terisi semua. Maka data akan tersimpan ke tabel pembayaran pada database.

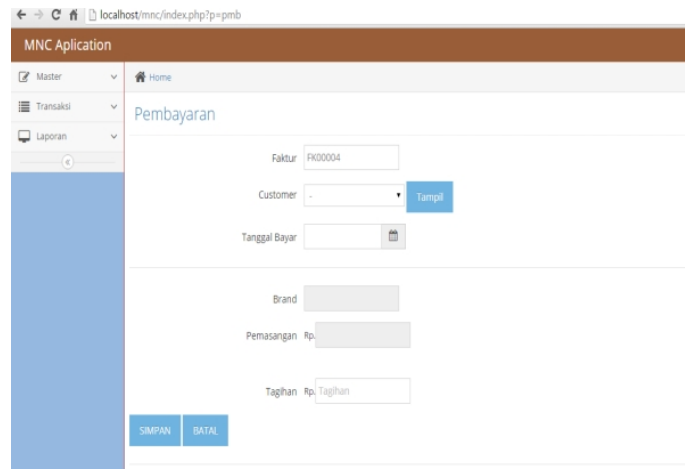

Gambar 9. Halaman Input Data Pembayaran

Layanan TV Pada halaman ini pengguna dapat mengakses dan melihat data customer yang jatuh tempo atau masa aktif layanan telah habis, dan memerlukan pembayaran langsung untuk mengaktifkan layanan tv langganan. Untuk melihat menu jatuh tempo langkah-langkah nya sebagai berikut :

1. klik menu laporan setelah itu klik sub menu jatuh tempo.

2. Jika customer yang terdaftar sudah habis masa aktif pembayaran layanan tv, maka data customer akan muncul di halaman jatuh tempo, jika belum habis maka data tidak ada dihalaman sub menu jatuh tempo.

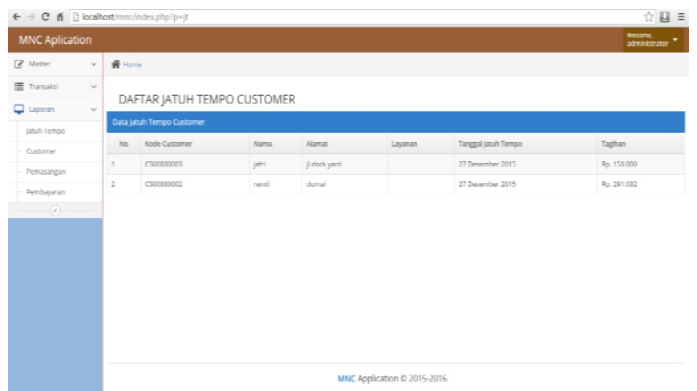

Gambar 10. Halaman jatuh tempo Customer

Pada halaman laporan data ini, pengguna dapat mengakses data laporan customer dan mencetaknya, berikut adalah langkahnya :

1. Klik menu tab data laporan, kemudian klik submenu customer.

2. Setelah muncul data customer.

3. Jika ingin mencetak data customer klik tombol cetak pada bagian atas tabel customer.

4. Setelah itu data laporan customer akan tampil.

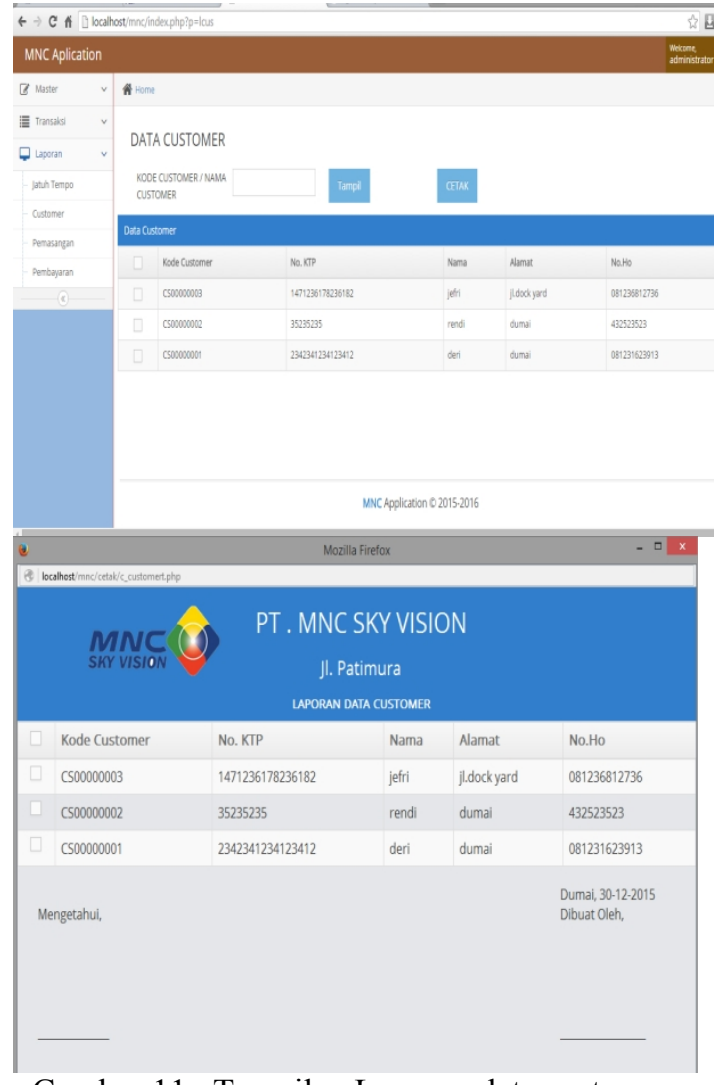

Gambar 11. Tampilan Laporan data customer

Pada halaman laporan data ini, pengguna dapat mengakses data laporan pemasangan layanan dan mencetaknya, berikut adalah langkahnya :

1. Klik menu tab data laporan, kemudian klik submenu pemasangan.

2. Setelah muncul data pemasangan.

3. Jika ingin mencetak data pemasangan klik tombol cetak pada bagian atas tabel pemasangan dan pilih cetak tahun atau bulan.

4. Setelah diklik maka muncul input cetak tahun atau bulan. Lalu klik tombol cetak.

5. Setelah itu data laporan pemasangan akan tampil. 
I N F O R M A I K A

Jurnal Informatika, Manajemen dan Komputer, Vol. 8 No. 2 , Desember 2016

eISSN : 2580-3042

pISSN : 1979-0694

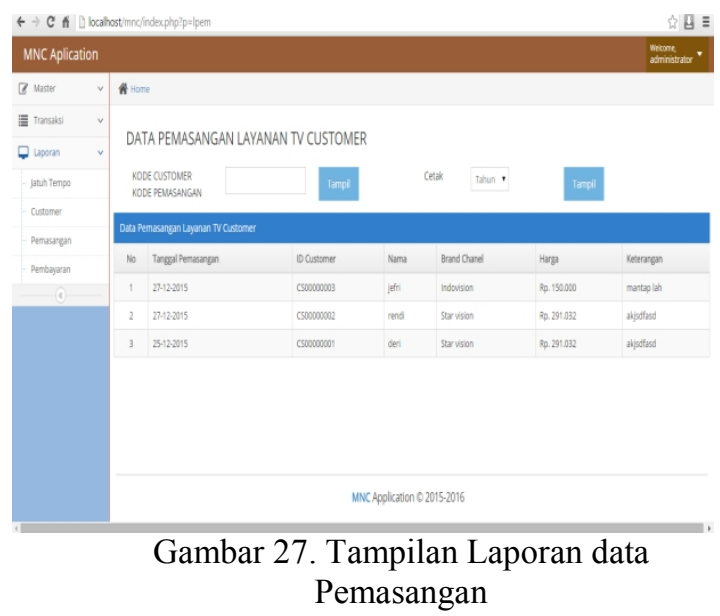

Henry Soelistyo.(2011).Plagiarisem: Pelanggaran Hak Cipta Dan Etika.Kanisius.Jakarta

Hernita P (at ed).(2010).Menguasai Pemrograman Web dengan JavaScript 2009.Andi.Semarang

Jogiyanto.(2009).Sistem Teknologi Informasi. Andi.Yoyakarta.

Ronald Rusli.(2013).Membuat Aplikasi GPS \& Suara Antrian dengan PHP.Lokomedia.Yogyakarta

Said Mirza P.(2013). Tujuh Langkah Praktis Pembangunan Basis Data.Elex Media Komputindo.Jakarta

\section{KESIMPULAN}

Berdasarkan hasil penelitian ini, dapat disimpulkan bahwa komputerisasi iformasi billing pada PT.MNC SKY VISION berbasis web ini mampu beberikan informasi tentang pembayaran tv prabayar maupun informasi tentang pelanggan itu sendiri. Hal tersebut membuat Pihak PT.MNC SKY VISION dapat menyampaikan informasi kepada pengguna atau masyarakat melalui website ini secara lebih mudah untuk lebih mengenal PT.MNC SKY VISION.

\section{REFERENSI}

Abdul Kadir.(2010). Mudah Menjadi Programmer Ajax.YesCom.Yogyakarta.

Abdul Kadir.(2009). From Zero to Pro Membuat Aplikasi Web dengan PHP + Database MySQL.Andi.Yogyakarta

Abdul Kadir.(2011). From Zero to Pro CSS.Andi.Yogyakarta

Adi Nugroho.(2011).PERANCANGAN dan IMPLEMENTASI SISTEM BASIS DATA.Andi.Yogyakarta

Agus Saputra.(2012). Membuat Aplikasi Absensi dan Kuesioner untuk Panduan kripsi. Elex Media Komputindo. Jakarta

Arie Prabawati (at Ed).(2010).Paling Dicari PHP Source Code. Andi.Semarang

Ayu Yudha (at ed).(2012).Web Programming for Beginners.Elex Media Komputindo.Jakarta

Edy Winarno.dkk.(2013).Buku Sakti Pemrograman PHP.Elex Media Komputindo.Jakarta.

Tata Sutabri.(2012). Konsep Sistem Informasi. Andi.Yogyakarta. 